\title{
„Dodatki”
}

\section{a kategoria jedności w poetyce klasycyzmu postanisławowskiego}

\author{
Helena Markowska
}

W ujęciu klasycystycznych tekstów ${ }^{1}$ poświęconych teorii poezji cechę dodatkowości wobec zasadniczej części dzieła literackiego można przypisać przede wszystkim pewnym fragmentom utworu zwanym epizodami lub, częściej, ustępami. Termin ten tak objaśnia w krótkim słowniczku zamykającym Wzory estetyczne poezji polskiej (1826) Józef Franciszek Królikowski:

Epizod - [...] tak nazywano w dramacie sceny pomiędzy śpiewem chóru wystawiane, bo wyraz ten oznaczał początkowo coś po śpiewie albo pomiędzy śpiewem będącego. Teraz epizodami nazywają te sceny, które się w przerwie czynności włączają, to jest takie, które niekoniecznie mają związek z głównym przedmiotem, mianując je ustępamì ${ }^{2}$.

Zgodnie $\mathrm{z}$ etymologią oraz $\mathrm{z}$ historycznym znaczeniem wyrazu, używanego $\mathrm{w}$ odniesieniu do starożytnego teatru greckiego, autor definicji najwyraźniej kojarzy epizod z dramatem, kiedy określa go jako „scenę” i wspomina o „czynnościach”, stanowiących w tradycji wywodzącej się od Arystotelesa przedmiot naśladowania dramatycznego. W traktujących o literaturze tekstach z epoki słowo „ustęp” pada wszakże znaczenie częściej w odniesieniu do epopei. Jeśli jednak wziąć pod uwagę, że także poemat bohaterski dotyczyć miał „czynu”, a dramatyczność powinna stanowić jedną z jego właściwości, zwłaszcza tam, gdzie bohaterowie przemawiają

\footnotetext{
${ }^{1}$ Określenia klasycyzm, odnosząc się do tzw. klasycyzmu postanisławowskiego, używam w szerokim sensie obejmującym teksty z lat 1795-1830 łączące nierzadko tradycję klasycystyczną z wpływami sentymentalizmu, rokoka i zjawisk preromantycznych. Zob. P. Żbikowski, Klasycyzm postanisławowski: doktryna estetycznoliteracka, Warszawa 1984.

2 J.F. Królikowski, Wzory estetyczne poezji polskiej w pięknościach pierwszych mistrzów naszych z przyłączeniem teoryi wystawione, Poznań 1826, s. 106.
} 
w mowie niezależnej, definicja Królikowskiego, nazywająca epizod „sceną”, da się stosować także i do epiki ${ }^{3}$. Przy tym być może to właśnie brak konotacji związanych z dramatem zaważył na tym, że chętniej posługiwano się polskim terminem „ustęp”, w którego polu znaczeniowym znajdowało się chwilowe odejście od rzeczy lub zawieszenie sprawy ${ }^{4}$ (w języku ogólnym oznaczał wtedy „odchylenie się na bok, na stronę”, a także np. przerwę w rozprawie sądowej).

Ten sam Królikowski pisze o poemacie bohaterskim: „Mimo jedności czynu mogą tu być ustę-

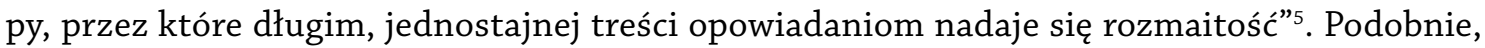
wykładając ogólne cechy epopei, stwierdza Euzebiusz Słowacki: „poeta może czynić ustępy, wprowadzić epizody, ale te wynikając z rzeczy celniejszej, nie powinny odrywać od niej uwagi”'. Spostrzeżenia dotyczące konkretnych scen padają nierzadko w tzw. rozbiorach, czyli wartościujących analizach budowy dzieł przeprowadzanych np. w wykładach akademickich. Ludwik Osiński mówi o epizodach w Iliadzie: „Wszelkie ozdoby i ustępy są tu z rzeczą najściślej związane"7, a bardziej szczegółowo o epizodach w Jerozolimie wyzwolonej:

Lecz komu jest przytomny ustęp Olinda i Sofronii, [...] ten uczuje zapewne, iż geniusz tylko, [...], mógł wydać w jednym pomyśle, co ma dzikiego zabobon i piekło, co rozrzewniającego widok dwojga [...] kochanków.

Wiele podobnych komentarzy czyni na temat literatury polskiej Kazimierz Brodziński. O poemacie Samuela ze Skrzypny Twardowskiego Władysław IV konstatuje: „Księgę trzecią tego dzieła można nazwać zupełnym ustępem"8, z kolei o Wojnie chocimskiej:

Przy oschłości opowiadania swego czuł Krasicki potrzeby ustępów. Ustęp pożegnania sędziwego Chodkiewicza z nowo zaślubioną małżonką nastręczał sposobność wystawić Polkę [...] czcią przejętą dla wodza chrześcijańskiej i narodowej sprawy. Sen tegoż [...] byłby przynajmniej stosowniejszy, wystawując nagrodę dawnych bohaterów narodu i przyszłe onego losy. Na koniec ustęp w czasie poselstwa do nadchodzącego Władysława w domku pustelnika przypomina dawne romanse i ani zajmuje, ani z poematem jakikolwiek ma związek ${ }^{9}$.

Pochlebniej wyraża się profesor-poeta o Jagiellonidzie Dyzmy Bończy-Tomaszewskiego: „Ustępy zajmują, ponieważ z obecnych zdarzeń i na własnej ziemi są wyszukane. Ustęp w drugiej pieśni jest podług mnie celujący" ${ }^{10}$. To samo dzieło krytykuje natomiast - wychodząc z klasycystycznych założeń dotyczących zasad budowy epopei - młody Adam Mickiewicz:

\footnotetext{
${ }^{3}$ O relacji między epopeją a dramatem zob. M. Piechota, Żywioł epopeiczny w twórczości Juliusza Słowackiego, Katowice 1993.

${ }^{4}$ S.B. Linde, Stownik języka polskiego, t. 6, Warszawa 1951, s. 182.

${ }^{5}$ J.F. Królikowski, Rys poetyki wedle przepisów teoryi w szczegółach z najznakomitszych autorów czerpanej, Poznań 1828, s. 75-76.

${ }^{6}$ E. Słowacki, O poezji, [w:] tegoż, Dzieła z pozostałych rękopismów ogłoszone, Wilno 1826, s. 98-99.

${ }^{7}$ L. Osiński, Wykład literatury porównawczej, [w:] tegoż, Dzieła, t. 2, Warszawa 1861, s. 26. Wykłady były wygłaszane na Uniwersytecie Warszawskim od 1818 roku.

${ }^{8}$ K. Brodziński, Literatura polska. Odczyty uniwersyteckie, [w:] tegoż, Pisma, t. 4, Poznań 1872, s. 194. Wykłady Brodzińskiego rozpoczęły się w roku 1822.

${ }^{9}$ Tamże, s. 333.

${ }^{10}$ Tamże, s. 410.
} 
jakkolwiek one [ustępy] wmieszane do głównej akcji przydają jej rozmaitości i wdzięku, same jednak poematu stanowić nie mogą, gdyż takie poema, nie mając żadnego interesu, byłoby, jak powiada Wolter, podobne do ram, w które według upodobania ustępy na kształt obrazków wstawiać i z których według upodobania dobywać je można. Jakoż przykład tego w Jagiellonidzie spostrzec się daje $\mathrm{e}^{11}$.

Nietrudno zauważyć, że cechą wspólną przytoczonych wypowiedzi jest ich normatywny charakter. Cytowanych teoretyków w „zagadnieniu ustępów” interesuje odpowiedź na pytanie, kiedy i jak można z pożytkiem wprowadzić epizody do utworu.

Aby zrozumieć udzielane przez nich odpowiedzi, należy poświęcić nieco uwagi kategorii estetycznej, wobec której rozpatrywana była kwestia „dodawania” fragmentów „niekoniecznie mających związek z głównym przedmiotem" - kategorii jedności. Kieruje to ponownie ku dramatowi, ponieważ $\mathrm{w}$ historii literatury zapamiętane zostały przede wszystkim osławione za sprawą polemiki romantyczno-klasycystycznej trzy jedności ${ }^{12}$. Zaliczenie reguły trzech jedności do „prawideł” (tych, o których pisał Maurycy Mochnacki, że są to „szczudła umysłowej niemocy partaczy" ${ }^{13}$ ) sprawia, że łatwo potraktować ją jako kategorię czysto techniczną. Tak na przykład Stanisław Pietraszko, rekonstruując doktrynę literacką polskiego klasycyzmu, stwierdza, że jako reguła dyspozycji, a nie inwencji, była ona w istocie drugorzędna ${ }^{14}$. Ten sam badacz podkreśla jednak, że wśród owych trzech jedności nie wszystkie miały równe znaczenie - niewątpliwie ważniejszą od dwóch pozostałych była jedność akcji ${ }^{15}$. Jako jedyna wywodziła się ona wprost z Poetyki Arystotelesa, podczas gdy pozostałe zostały wyprowadzone przez teoretyków nowożytnych z praktyki teatru greckiego, co też dało silny argument ich przeciwnikom, np. Franciszkowi Wężkowi:

Krytycy francuscy, którzy tak mocno przy zachowaniu trzech jedności obstają, twierdzą, że je wraz z innemi przepisami sztuki wyczerpali od Greków [...]. Nie będziemy się nad tem rozwodzić, czyli podług Szlegla Arystoteles w swojej poetyce ciemno o jedności czasu, a nic o jedności miejsca nie pisał, czyli też według pisarzy francuskich ten mędrzec i krytyk podał pewne i niecofnione w tej mierze prawidła. [...] przypuściwszy, że Grecy te lub tym podobne zachowywali prawidła, chcemy najprzód okazać, jaka jest różnica między dramatyką grecką a naszą ${ }^{16}$.

Jak zauważa Dobrochna Ratajczak, w XVIII wieku narasta napięcie pomiędzy praktyką sceny wykorzystującej nowe możliwości techniczne, np. do zmiany dekoracji, a literaturą obstająca

\footnotetext{
${ }^{11}$ A. Mickiewicz, Uwagi nad Jagiellonidą D. Bończy Tomaszewskiego, [w:] tegoż, Dzieła, t. 5: Proza artystyczna i pisma krytyczne, Warszawa 1996, s. 82.

${ }^{12}$ Dla przykładu, w Słowniku terminów literackich hasła „jedność czasu”, ,jedność miejsca” i „jedność akcji” (nie ma osobnego hasła „jedność”) odsyłają do wspólnego hasła „trzy jedności” (Słownik terminów literackich, red. J. Sławiński, Wrocław 1988, s. 207).

${ }^{13} \mathrm{M}$. Mochnacki, Niektóre uwagi nad poezją romantyczną z powodu rozprawy Jana Śniadeckiego, [w:] tegoż, Rozprawy literackie, oprac. M. Strzyżewski, Wrocław 2000, s. 87.

${ }^{14}$ S. Pietraszko, Doktryna literacka polskiego klasycyzmu, Wrocław 1966, s. 317.

${ }^{15}$ Tamże, s. 319: „Reguła jedności akcji, najpoważniejsza, bo sformułowana jeszcze w starożytności i nadto obowiązująca w poezji wszystkich gatunków”.

${ }^{16}$ F. Wężyk, O poezji dramatycznej, [w:] Archiwum do Dziejów Literatury i Oświaty w Polsce, t. 1, Kraków 1878, s. 284.
} 
za utrzymaniem jedności czasu i miejsca ${ }^{17}$. Wynikiem toczących się dyskusji jest stanowisko wielu polskich teoretyków okresu postanisławowskiego, uznających, że wprawdzie każdy akt powinien trwać tyle, ile zajmuje jego odegranie i odbywać się w jednym miejscu, jednak na mocy umowy między autorem a publicznością w przerwach przedstawienia upływa pewien czas akcji, którą można wykorzystać na przeniesienie bohaterów w inne miejsce. Pisze o tym Wężyk:

to dzieło dramatyczne co do jedności czasu najlepszem jest, które nie trwa dłużej nad czas do wystawienia potrzebny; to zaś nie chybia przeciw naturze rzeczy i dzisiejszego teatru, które się przez tyle dni ciągnie, ile ma aktów. [...] sądzę, że nie odmieniając bynajmniej miejsca w aktach samych, jeden z nich może się odbyć w pałacu, inny w ogrodzie, inny w więzieniu, w kościele”18.

Nawet uchodzący za nieprzejednanego klasyka Osiński postuluje:

strzeżmy się mniej rozważnie potępiać dzieła, w których autor w obrębie niezbyt rozległym wystawia nam te wszystkie miejsca, gdzie jego aktorowie z konieczności działać i słuchacze z konieczności obecnemi być muszą ${ }^{19}$.

Stanowisko to wynika, jak się zdaje, nie tylko z przemian w teatrze europejskim i pojawienia się nowych wzorów estetycznych (przede wszystkim twórczości Szekspira, którego admiratorem był Wężyk, ale którego chwalił, choć wybiórczo, nawet Osiński). Dwie jedności - czasu i miejsca - można rzeczywiście uznać za wskazówki dotyczące „dyspozycji” sztuki. Nie arbitralne jednak, ale wynikające z ogólniejszych zasad: prawdopodobieństwa i „najdoskonalszego zmysłowego wystawienia" ${ }^{20}$. To z powodu podporządkowania tym dwu względom obydwie jedności były w omawianej epoce traktowane elastycznie.

Takie postawienie sprawy jedności pozwala, jak sądzę, zweryfikować jeszcze jedno przekonanie pojawiające się wśród spostrzeżeń dotyczących klasycystycznej tragedii. Wedle tego przekonania ujęcie materiału historycznego $\mathrm{w}$ troistą jedność (wszystkie trzy reguły są w tym wypadku traktowane koniecznie razem) miało na celu uniwersalizację przedmiotu sztuki. Zastosowanie wiecznych reguł przenosiło utwór do wieczności. Zwłaszcza jedność czasu

${ }^{17}$ D. Ratajczak, Wstęp, [w:] Polska tragedia neoklasycystyczna, wybór i opracowanie D. Ratajczak, Wrocław 1988, s. LXXVI.

${ }^{18} \mathrm{~F}$. Wężyk, O poezji dramatycznej, s. 286. Analogiczne stanowisko wyraża Euzebiusz Słowacki: „prawidło to jedności miejsca przez najlepszych poetów dramatycznych nieco rozwolnione zostało. Nie wolno jest przenosić scenę z miasta do miasta i z kraju do kraju, [...] ale jeżeli okoliczność wymaga i podobieństwo do prawdy na tem nie cierpi, odmiana sceny $\mathrm{z}$ aktu do aktu nie jest wzbroniona, byleby miejsce było tak bliskie, izby się można do niego przenieść w tym czasie, który między dwoma aktami podług założenia poety mógł upłynąć. [...] Między jednym i drugim aktem może upłynąć kilka lub kilkanaście godzin, poranek, wieczór lub noc cała" (E. Słowacki, O poezji, s. 122-123) czy Józef Korzeniowski: „Przemiana miejsca w międzyaktach nie przerywa nawet zmysłowego złudzenia [...]. Przedłużenie czasu może mieć miejsce przez przemianę dekoracji, a szczególniej w miedzyaktach, brak bowiem działania w tych przerwach zostawia czas nieoznaczonym" (J. Korzeniowski, Kurs poezji, Warszawa 1829, s. 213-214).

${ }^{19}$ L. Osiński, Wykład literatury porównawczej, t. 3, s. 43.

${ }^{20}$ Zasady prawdopodobieństwa i „najdoskonalszego zmysłowego wystawienia” Piotr Żbikowski wymienia wśród reguł tworzących wspólną podstawę teorii literackiej klasycyzmu postanisławowskiego, „praktycznych, a jednocześnie normatywnych i obligatoryjnych wskazówek, [...] określających przede wszystkim strukturę świata przedstawionego oraz relacje łączące go z tzw. realną rzeczywistością" (P. Żbikowski, Klasycyzm postanisławowski..., s. 81). 
i miejsca miałyby sprawiać, że wydarzenia dramatu przenoszą się w czas pozahistoryczny. Tak traktuje to zagadnienie Ryszard Przybylski, dla którego prawidło jedności ma charakter „metafizyczny”, choć świadomość tego charakteru obecna u XVII-wiecznych klasyków francuskich uległa zatarciu w XVIII wieku ${ }^{21}$. Do odwrotnych wniosków dochodzi Ratajczak, która pisze, że w XVII wieku dramat klasycystyczny „dbał o wywołanie iluzji realności tworzonego przez siebie świata. Temu właśnie służyła osławiona «klatka» trzech jedności” ${ }^{22}$, dalej zauważa jednak, że w efekcie przemian sztuki teatralnej „trojaka jedność stawała się wyrazem dążenia twórcy do nadania dziełu cech trwałości przez poddanie go wiecznym prawom literatury, wyzwalającym je spod wpływu chwilowych tylko praw teatru" ${ }^{23}$. W efekcie oboje badacze są skłonni w klasycystycznej formie widzieć sposób obrony przed chaosem historii (Ratajczak ${ }^{24}$ ) czy rozpadem jednostki, dzięki duchowi matematyki (Przybylski ${ }^{25}$ ). Nie rozstrzygając tej kwestii w odniesieniu do tragedii francuskiej, ani nie wypowiadając się o efekcie, jaki ostatecznie został osiągnięty w klasycystycznych utworach dzięki zastosowaniu reguł, należy podkreślić, że podobne rozumienie prawidła trzech jedności nie było wyrażane w polskich tekstach teoretycznych w czasie, kiedy powstawała polska tragedia klasycystyczna (a więc na początku XIX wieku). Oprócz już cytowanych wypowiedzi, wskazujących na znaczenie zastosowania reguł dla stworzenia iluzji teatralnej, można przytoczyć w tym miejscu podręcznik Królikowskiego:

Patrzący mają być świadkami całej akcji, powinna się przeto na jednem, temże samem miejscu odbywać, ażeby ułudzenie gwałtownie przerywane nie było. [...] Czyn jaki w swojem zaczęciu, zawikłaniu i rozwiązaniu w przeciągu niewielu godzin odbyć się w oczach widzów powinien, tak ażeby nienaturalne skrócenie czasu nie osłabiało wrażenia, które na umyśle widzów zadziałać ma ${ }^{26}$.

Czy wierszowaną Sztukę rymotwórczq̨ Ludwika Kropińskiego:

Jedno lub mało zmienne miejsce naznacz scenie.

I strzeż, aby słuchacze nie uczuli w niczem,

Że co mówisz i działasz, wszystko jest zwodniczem.

Przykuj do twojej sztuki ich serca i myśli,

By $z$ tych omamień nawet na chwilę nie wyszli²

Wszystko wskazuje na to, że jedność utworu dramatycznego, a więc brak gwałtownych przeskoków czasowych czy epizodów rozgrywających się w innych miejscach, miała przede wszystkim umożliwić widzowi poczucie uczestnictwa w konkretnym, fizycznie rozgrywającym się odbywającym się w danym miejscu i czasie wydarzeniu, nie zaś przenieść go w sferę wieczności.

Jak zatem rozumieć kategorię jedności tak, by nie traktować jej jako czysto technicznego wy-

${ }^{21}$ R. Przybylski, Klasycyzm, czyli prawdziwy koniec królestwa polskiego, Gdańsk 1996, s. 259.

${ }^{22}$ D. Ratajczak, Wstęp, s. LXXV.

${ }^{23}$ Tamże, s. LXXVI.

${ }^{24}$ Tamże, s. XLII.

${ }^{25}$ R. Przybylski, Klasycyzm..., s. 62.

${ }^{26}$ J.F. Królikowski, Rys..., s. 94-95.

${ }^{27}$ L. Kropiński, Sztuka rymotwórcza, [w:] tegoż, Rozmaite pisma, Lwów 1844, s. 129. 
mogu, który wraz z przemianami sztuki scenicznej stał się anachronizmem i w końcu został osłabiony i zniesiony, ale zarazem nie przypisywać jej właściwości metafizycznych? Kluczowa wydaje się opisana różnica pomiędzy jednością akcji a jednością czasu i miejsca łączonymi $\mathrm{z}$ nią, chyba także w tekstach z epoki, często jakby dla łatwości wykładu i rozpoznawalności hasła „trzech jedności”. Zacytujmy Euzebiusza Słowackiego:

\begin{abstract}
Wszelkiej sprawy poetycznej jedność powinna być zawsze istotnym przymiotem, ale ponieważ w dramatach rzecz nie tylko się opisuje i opowiada, ale nawet wystawia się przed oczy patrzących, przeto poeta, dla sprawienia na słuchaczach potrzebnego omamienia, nie tylko jest obowiązanym do zachowania najściślejszej jedności akcji, ale nawet do zachowania jedności miejsca i czasu: i to jest, co troistą jednością w poezji dramatycznej nazywać się zwykło²8.
\end{abstract}

W przypadku utworu realizowanego w teatrze reguły służące stworzeniu iluzji przekonującej dla widza były szczególnie ważne, jako że „najdoskonalsze zmysłowe wystawienie” dokonywało się przed jego oczami, a nie jedynie w wyobraźni. Z przywołanego fragmentu wynika wszakże, że jedność akcji - związana bezpośrednio z regułami dotyczącymi wplatania w tok utworu epizodów - jest zasadą wyższego rzędu (podobnego co wspomniane już zasady prawdopodobieństwa czy najdoskonalszego zmysłowego wystawienia) oraz zagadnieniem znaczenie wykraczającym poza dziedzinę dramatu.

Teoretycy z epoki powtarzają zgodnie, że jedność jest podstawową cechą dobrze zbudowanej epopei. „Najistotniejszym przymiotem sprawy, która jest materią epopei, ma być jedność” stwierdza Euzebiusz Słowacki ${ }^{29}$. Wtóruje mu Ludwik Osiński: „Bez pewnej jedności rzeczy nie masz, ściśle mówiąc, poematu" ${ }^{30}$. Królikowski pisze:

[...] sama rzecz poematu powinna być jedną całością, która z wielu połączonych części powstaje. Poeta zawsze pamiętać powinien o tem, ażeby spólne do jednego celu dążenie zachodziło nie tylko w zdarzeniach, ale nawet w charakterach, namiętnościach i czynności działających osób ${ }^{31}$.

Jedność powinna także charakteryzować odę (o czym tak pisze Korzeniowski: „Każde zatem poema, nie wyłączając i ody, powinno mieć przymiot jedności, części jego powinny stanowić jednę całość i wiązać się z sobą” ${ }^{32}$ ), poezję dydaktyczną („Takie poema powinno mieć główną treść i spólny przedmiot całości, to jest wszystkie części prawd i nauk powinny dążyć do jednego celu" ${ }^{33}$ - stwierdza Królikowski), a nawet drobne utwory, takie jak bajka (u tegoż czytamy: „Jedność przedmiotu w bajce wynika stąd, kiedy pojedyncze okoliczności i części ku jednemu zgadzają się celowi” ${ }^{34}$ ). Należy ją respektować nie tylko pisząc poezję, lecz także, jak mówi Stanisław Kostka Potocki: „jedność powinna być pierwszym historyka baczeniem”35.

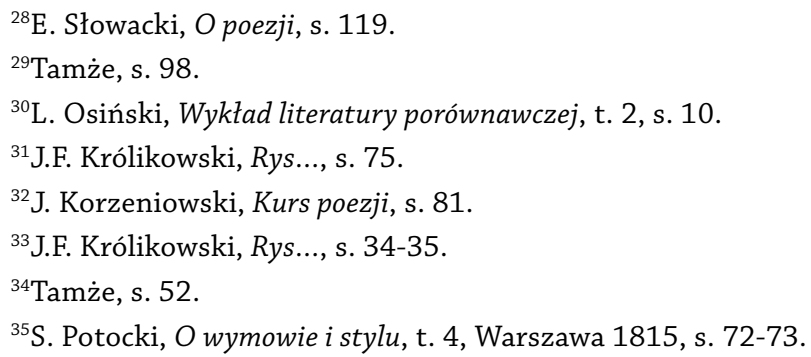


Definicja tak powszechnie postulowanej jedności pozostaje bardzo ogólna. Polega ona na podporządkowaniu wszystkich działań jednemu celowi, na niezbędności wszystkich elementów utworu i jego swoistej niepodzielności. Euzebiusz Słowacki pisze:

Wszyscy, którzy pisali o piękności, uznają jedność za jej zasadę i charakteryzującą cechę. Jedność sprawuje, iż rzeczy rozliczne i mnogie stają się częściami jednej rzeczy, co należy na takiem połączeniu części, aby to połączenie nie dozwalało nam brać jednej rzeczy za rzecz zupełnie oddzielną ${ }^{36}$.

Daleko łatwiej definiować ją w odniesieniu do poszczególnych gatunków. Zwłaszcza trzy najwyższe wymagają szczególnej troski o jedność. W epopei zasadza się ona na przedstawieniu jednego działania, z którego wszystkie inne wydarzenia wynikają. Przedmiot poematu bohaterskiego powinien być na tyle jednolity, by dał się ująć w kilku wersach inwokacji. W ten sposób rozpoczęcie utworu od określenia jego tematu nie tylko motywowane jest tradycją, lecz także stanowi potwierdzenie sprawności konstrukcyjnej poety. Ludwik Osiński pisze o otwarciu Iliady:

W tych słowach mieści się cała treść, cały układ poematu. Gniew Achillesa składa osnowę Iliady, nie idzie w niej o zdobycie Troi, nie idzie nawet o pomszczenie brata Agamemnona. Ale te wszystkie względy, cała walka spór wiodących narodów, ich przeznaczenia, dzieje, ich charaktery, wielkie tylu wojowników obrazy, więcej powiem, ludzkość i bogi, prawdy i zmyślenia, błędy i nauki, związki rodzinne, odgadnione serc ludzkich skrytości, w niewielkiej osnowie, w jednym szczególnym czynie jaśnieją ${ }^{37}$.

W tragedii istotą jedności jest przede wszystkim to, aby każda scena posuwała naprzód akcję, czyli, mówiąc słowami Piotra Żbikowskiego, jej istotą jest zasada „absolutnej konieczności poszczególnych [...] elementów i ich przyczynowo-skutkowej więzi" ${ }^{38}$. Korzeniowski objaśnia to zagadnienie w następujący sposób:

[...] osoby wchodzące do dramatu mogą mieć różne zamiary i cele, lecz powinny one być połączone z głównym zamiarem przez tosamość lub przeciwność; powinny służyć do przyspieszenia lub oddalenia rozwiązania i zbiegać się w jeden punkt tak, iżby się wszystkie przez jednę katastrofę przerwać mogły ${ }^{39}$.

A Osiński przy okazji krytyki Dziewicy Orleańskiej Schillera zauważa: „Nie dosyć jest piękną scenę utworzyć, o to się jeszcze starać należy, aby ta scena była potrzebą" ${ }^{40}$. Wreszcie w odzie jedność dotyczy uczucia, które stanowi emocjonalną dominantę całego wiersza („Jedność przedmiotu, to jest jedność uczucia udzielającego natchnienia poecie, jest ważnym warunkiem ody" ${ }^{41}$ - pisze Korzeniowski).

\footnotetext{
${ }^{36}$ E. Słowacki, Teoria smaku w dziełach sztuk pięknych, [w:] tegoż, Dzieła z pozostałych rękopismów ogłoszone, t. 1, Wilno 1827, s. 55.

${ }^{37} \mathrm{~L}$. Osiński, Wykład literatury porównawczej, t. 2., s. 13.

${ }^{38}$ P. Żbikowski, Klasycyzm postanisławowski..., s. 265.

${ }^{39} \mathrm{~J}$. Korzeniowski, Kurs poezji, s. 207.

${ }^{40}$ L. Osiński, Wykład literatury porównawczej, t. 3., s. 14.

${ }^{41} \mathrm{~J}$. Korzeniowski, Kurs poezji, s. 79.
} 
Wobec gatunkowego zróżnicowania sposobów realizacji jedności w tekstach można zatem zapytać, co stanowi o jedności samej kategorii jedności. Otóż we wszystkich wspomnianych typach utworów jest ona pożądana ze względu na adresata, który chce postrzegać utwór jako jeden przedmiot. Przy tym teoretycy piszą przede wszystkim o skutkach, jakie ma dla odbiorcy niezachowanie jedności. Uderzająca zgodność rozpoznań i ich nieoczywistość dla współczesnego czytelnika skłaniają do przytoczenia większej liczby cytatów, które następnie zbiorczo skomentuję:

Słowacki: Kiedy więc w rzeczy, którą rozważamy, nie znajdujemy jedności, zamiast przyjemnego uczucia doznajemy przykrości i cierpienia i rzecz taka nie może nam się podobaćt2.

Osiński: Dwie akcje, mówi jeden z uczonych, razem i w tymże samym poemacie prowadzone musiałyby koniecznie albo równo zajmować, albo jedna drugą przewyższać. W pierwszym razie serce słuchacza zostawałoby w przykrej niepewności, do którego celu ma swoje czucia przywiązać. W drugim rzecz mniej zajmująca ustąpiłaby pierwszeństwa ważniejszej, a tak stać by się musiała dla tego samego nie miłą, że główniejszy interes przerywa i studzi ${ }^{43}$.

Wężyk: Podwójne działanie musi rozerwać uwagę słuchacza, a niepewność i wahanie się jego za sobą pociągnąć. Lecz dążenie wszystkich osób do jednego zamiaru [...] wystawi owo ścieranie się uczuć i walkę namiętności, w których nierozdwojone serce idzie za przedmiotem uwielbienia swojego, towarzyszy mu we wszystkich czynach, z nim razem cierpi lub działa, cieszy się lub smuci $^{44}$.

Królikowski: Jeżeli nas poezja poruszać, pociągać ma, akcja powinna być szczególna, co zawisło albo od rzeczy samej, albo od sposobów, których używamy do dojścia do celu: jedność utrzymuje uwagę naszę. Zbyteczne zawikłanie utrudza, zbyteczna pojedynczość nudzi, położenia i charaktery zbyt jednostajne sprawują niesmak, wypadek nadzwyczajny i obcy mniej czyni zadość; dusza raz poruszona, nie lubi oddalać się od celu ${ }^{45}$.

Korzeniowski: Przykro bowiem zajmować się drobnemi lub komicznemi wydarzeniami wtenczas, gdy się kto oddaje podziwieniu lub sympatii, gdy serce jego przepełnia się tkliwemi lub podnoszącemi uczuciami ${ }^{46}$.

Piękno powinno zatem wywoływać w postrzegającym uczucie przyjemności, tymczasem brak jedności w dziele sztuki sprawia, że odbierając je, doznajemy przykrości (cierpienia, utrudzenia). Zdaniem przywoływanych teoretyków przykrość ta wynika przede wszystkim z konieczności podziału uwagi, za którym idzie niemożność emocjonalnego zaangażowania, lub też $\mathrm{z}$ konieczności zmiany przedmiotu zainteresowania w trakcie odbioru tekstu.

\footnotetext{
${ }^{42}$ E. Słowacki, Teoria smaku..., s. 55.

${ }^{43}$ L. Osiński, Wykład literatury porównawczej, t. 2., s. 14.

${ }^{44} \mathrm{~F}$. Wężyk, O poezji dramatycznej, s. 283.

${ }^{45} \mathrm{~J}$. F. Królikowski, Rys..., s. 12.

${ }^{46} \mathrm{~J}$. Korzeniowski, Kurs poezji, s. 18.
} 
Konstatacje na temat kategorii jedności są, jak widać, głęboko zakorzenione w teorii percepcji, a nawet ogólniej - teorii poznania. Według Słowackiego w naszej naturze leży to, że staramy się pojąć rozumowo wszystko, czego dostarczają nam zmysły. W tym celu tworzymy „wzór idealny" tego, czym naszym zdaniem jest percypowany przedmiot. Wzór ów musi charakteryzować się jednością, innymi słowy być jeden dla jednego przedmiotu, albowiem, jak pisze wileński profesor, „jedność jest formą myśli ludzkiej”ㄱ. Tak więc przykrość towarzysząca niemożności utworzenia sobie na podstawie dzieła sztuki jednego wzoru idealnego, do którego będzie pasowało, a co za tym idzie pojęcia go jako jednego przedmiotu, wynika z niespełnionej chęci poznania tego, czym dzieło w istocie jest. Potocki stwierdza: „Rozum nie może nigdy uważać jasno i wyraźnie, jak jeden tylko przedmiot" ${ }^{\text {". W }}$ W przytoczonych wypowiedziach odnajdujemy Kartezjańskie podstawy teorii estetycznej klasycyzmu, które tak w odniesieniu do teorii dramatu relacjonował Stanisław Pietraszko:

Ciągłość działania umysłu w procesie poznania, tak często przez Kartezjusza podkreślana jako warunek osiągnięcia pewności w poznaniu, dotyczyła i tego typu indukcji, jak odbiór przez widza teatralnego przebiegu narastającej „sprawy” dramatu. Znajdował tu zastosowanie kolejny postulat, aby intelekt, mający się posłużyć wyobraźnią dla wyrażenia idei, redukował „mnogość przedmiotów" tej idei odpowiadających do reprezentatywnej jednostkowości ${ }^{49}$.

Takie rozumienie źródeł kategorii jedności utworu literackiego pozwala zatem, jak sądzę, podkreślić jej nakierowanie na odbiorcę i jego satysfakcję poznawczą, którą zapewnia zastosowanie pewnych reguł budowy tekstu, i zarazem nie utracić filozoficznego znaczenia tej kategorii - nie metafizycznego jednak, ale epistemologicznego.

Jasne staje się teraz, że ocena wszystkich obecnych w utworze „ustępów” musiała każdorazowo zależeć od odpowiedzi na pytanie, czy naruszają one, czy też nie, jedność dzieła. Wśród wskazówek mających pomóc twórcom wprowadzać do swoich tekstów epizody panuje zróżnicowanie podobne do tego, które można było zaobserwować przy wskazywaniu wykładników jedności w różnych gatunkach literackich. Teoretycy są zatem zgodni co do tego, że w utworze dramatycznym, a zwłaszcza w tragedii, epizody nie powinny w ogóle się pojawiać ${ }^{50}$. Główny wątek ma docierać do odbiorcy „ubocznymi czynnościami i ustępami nie osłabiony” ${ }^{1}$, a ponieważ każda scena musi posuwać akcję naprzód, fragmenty, które się „w piątym nawet akcie z głównem działaniem nie łączą, zawsze są uchybieniem" ${ }^{22}$ (jak strzelba Czechowa, która nie powinna wisieć na ścianie, jeśli ma nie wystrzelić).

\footnotetext{
${ }^{47}$ E. Słowacki, Teoria smaku..., s. 55.

${ }^{48}$ S. Potocki, O wymowie i stylu, s. 54.

${ }^{49}$ S. Pietraszko, Doktryna literacka polskiego klasycyzmu, s. 330.

${ }^{50}$ Wężyk - bardzo jak na swoje czasy liberalny teoretyk dramatu - pisze: „Dozwolone w innych poezji rodzajach ustępy (epizody) niezgodne są z przyrodzeniem dramatycznej poezji” (F. Wężyk, O poezji dramatycznej, s. 283).

${ }^{51}$ J.F. Królikowski, Rys..., s. 94.

${ }^{52}$ Tamże, s. 97-98. Ciekawy przykład krytyki konkretnego dramatu, także z wykazaniem, które sceny są zbędne z punktu widzenia rozwoju akcji, stanowi recenzja Samoluba J.U. Niemcewicza pióra Leona Borowskiego, zob. L. Borowski, Rozbiór „Samoluba”, komedii w V aktach wierszem J.U. Niemcewicza, [w:] tegoż, Uwagi nad poezją i wymowq $i$ inne pisma krytycznoliterackie, Warszawa 1972. Wiele rozbiorów, prowadzonych również pod tym kątem, zawierają wielokrotnie tu przywoływane Wykłady z literatury porównawczej Osińskiego.

W najobszerniejszej ich części poświęconej dramatowi znajdziemy analizy m.in. o Makbeta, Cyda, Horacjuszy, Dziewicy Orleańskiej.
} 
Do ciekawych wniosków dotyczących różnic pomiędzy statusem ustępów w dramacie i epopei może prowadzić przeanalizowanie dwóch użyć tej samej metafory zaczerpniętej od A.W. Schlegla, który powiedział, że epizody w utworze powinny być jak odnogi rzeki - oddzielające się od niej, ale na powrót wpadające do głównego nurtu. Franciszek Wężyk przywołuje ją z dezaprobatą i stwierdza, mówiąc dalej językiem Schlegla, że odnoga, która odpłynie za daleko, nie ma już szans powrócić do rzeki, z której wzięła początek ${ }^{53}$. Tymczasem Euzebiusz Słowacki aprobuje i rozbudowuje tę metaforę (nie powołując się wprawdzie wprost na Schlegla): „Rozdziela się [rzeka] na rozmaite odnogi, ramionami ogarnia wyspy, potoki, strumienie i nowe rzeki przyjmuje do swego łona, lecz czyli to jednem, czy wielą ujściami wpada w Ocean, zawsze jest jedną i tąż samą rzeką"54. Odnotowując tę różnicę zdań, należy zauważyć, że Wężyk pisze o dramacie, natomiast Słowacki za pomocą przywołanej metafory opisuje właściwości epopei.

W epopei bowiem - $\mathrm{i}$ było to mniemanie powszechne - ustępy są nie tylko dopuszczalne, lecz także pożądane. Wynika to z samej długości utworu, a co za tym idzie - odbioru diametralnie innego niż w przypadku dramatu. Oglądający przedstawienie widz nie chce, aby coś przerywało główną intrygę, którą śledzi z zainteresowaniem, przy tym wszystko, co pojawi się na scenie, jako unaocznione, musi silnie przyciągać jego uwagę. W epopei natomiast prosta, lecz obszernie opowiedziana historia mogłaby znużyć, gdyby nie epizody wprowadzone do utworu jako „przerwy i spoczynki” 55 nadające mu „rozmaitość” ${ }^{56}$. W tekście przeznaczonym do lektury autor jest w stanie osiągnąć to, że również podczas poznawania epizodów odbiorca będzie miał stale w pamięci główny wątek utworu, tak jak dzieje się to, zdaniem Osińskiego, w Iliadzie:

Zdumiewa nas ta rozmaitość zdarzeń, mów, bitew, uczuć, charakterów i obyczajów, zachwyca bogactwo tylu najpiękniejszych ustępów, lecz to najwięcej zniewala, to przywiązuje, że nic w całym ciągu poematu nie usuwa $z$ uwagi naszej głównego przedmiotu, jakim jest obraza Achillesa ${ }^{57}$.

Oprócz analizy doskonałych wzorów, takich jak Iliada, i uwag ogólnych, poszukujący zasad trafnego wprowadzania ustępów do utworu epickiego mógł znaleźć także konkretne wskazówki. Przedstawia je Korzeniowski w Kursie poezji58. Po pierwsze, ustępy powinny naturalnie wynikać $\mathrm{z}$ fabuły poematu, a im mniej są z nią związane, tym powinny być krótsze. Po drugie, powinny wyróżniać się tematyką od fragmentów poprzedzających je i następujących po nich, gdyż inaczej nie dostarczą czytelnikowi odpoczynku, któremu służą (tak więc „epizod

\footnotetext{
${ }^{53} \mathrm{~F}$. Wężyk, O poezji dramatycznej, s. 283.

${ }^{54}$ E. Słowacki, O poezji, s. 99.

${ }^{55}$ Korzeniowski pisze, porównując właśnie epopeję i tragedię: „Że akcja epopei daleko obszerniejsza więcej zamyka w sobie okoliczności, że jej postęp może być powolny, dopuszczający nawet pewnych przerw i spoczynków, w których poecie epizodami lub uwagami ogólnemi z treści wynikającemi, lub nawet sobą, swoiemi myślami i uczuciami, czytelników zająć pozwolono (J. Korzeniowski, Kurs poezji, s. 152).

${ }^{56}$ Tak o epizodach w epopei wypowiada się Królikowski: „Mimo jedności czynu mogą tu być ustępy, przez które długim, jednostajnej treści opowiadaniom nadaje się rozmaitość, ale te ustępy powinny z samej rzeczy głównej albo z okoliczności z nią związanych być wyciągnione i wzmacniać dzielność głównego przedmiotu" (J.F. Królikowski, Rys..., s. 75-76). Rozmaitość była jedną z często przywoływanych w epoce kategorii estetycznych, zob. E. Słowacki, Teoria smaku..., s. 59.

${ }^{57}$ L. Osiński, Wykład literatury porównawczej, t. 2, s. 13.

${ }^{58} \mathrm{~J}$. Korzeniowski, Kurs poezji, s. 154-156.
} 
wojenny wśród wojny nie byłby na swoim miejscu"59). Po trzecie, powinny pojawiać się tam, gdzie w toku głównej akcji następuje pewna przerwa albo rozgrywają się wydarzenia, których poeta nie zamierza przedstawiać, nie zaś w punkcie, w którym gwałtownie przerwałyby tok opowieści. Wreszcie podkreśla się, że epizod musi być starannie wykończony artystycznie, ponieważ jego głównym celem jest ozdoba poematu. Warto też wspomnieć, że Korzeniowski wprowadza określenie „wydarzenia przydatkowe” na oznaczenie poszczególnych zdarzeń składających się na główny wątek. Tak na przykład pojedynek Parysa z Menelaosem w Iliadzie będzie wydarzeniem przydatkowym, ponieważ należy do ciągu dziejów wojny, choć jest osobną sceną, natomiast pożegnanie Hektora z Andromachą będzie epizodem, ponieważ można je pominąć bez szkody dla akcji utworu.

Ta stosunkowo łatwa definicja epizodu sformułowana w odniesieniu do utworu fabularnego nie daje się zastosować do ody - w której charakterystyce posługiwano się jednak często terminem „ustęp”. „Ustępy i zboczenia, czyli epizody [...] w tym rodzaju rymoworstwa przyzwoite mają miejsce"60 - pisze Słowacki. Należy przypomnieć, że jedność utworu lirycznego opierała się na jedności uczucia kierującego podmiotem mówiącym. W odzie powinna to być silna namiętność, która nasuwa myśli zbyt szybko, by wszystkie mogły zostać zapisane. Taka teoria ody prowadzi w istocie do tego, że składa się ona z szeregu obrazów-ustępów, gdyż:

Myśli pośrednie, które częściej się z sobą połączają, ale same nie mając najwyższego stopnia żywości, pomija poeta, zostawiając je czytelnikowi, i stąd to tylko wynika pozorny nieporządek, który odzie przypisujemy. Ta uwaga wskazuje, jakie w odach dozwolone są porównania, ustępy i uboczne obrazy, które z nich należy dotknąć tylko w głównym zarysie i jak należy unikać rozpierzchnienia się myśli od głównego przedmiotu ${ }^{61}$.

W ten sposób, dzięki niezmienności tematu i uczucia (może ono jedynie zmieniać natężenie, ale nie ogólny „ton”), które temat ten wywołuje, dobrze zbudowana oda także ściśle zachowuje zasadę jedności.

W odniesieniu do każdego z omówionych gatunków literackich „ustęp” czy „epizod” był więc rozumiany nieco inaczej; mógł być elementem nieakceptowanym, mile widzianym czy wręcz pożądanym. Nie ulega natomiast wątpliwości, że oba określenia w omawianej epoce funkcjonowały w tekstach o literaturze jako terminy i były powiązane z całą serią przepisów konstrukcyjnych określających, jak powinno się wprowadzać owe dodatkowe fragmenty do treści utworu. Nie były to przepisy arbitralne, wywodzone jedynie z tradycji literackiej czy nawet z „dobrych wzorów”, ale podporządkowane naczelnej zasadzie jedności. Również sama jedność - co wydaje się wnioskiem najważniejszym - nie była właściwością autoteliczną. Choć w ujęciu teoretyków klasycystycznych z początku XIX wieku istniała oczywiście immanentnie w dziele sztuki, była jego obiektywną cechą realizującą się zwłaszcza w kompozycji utworu, to jej cel wiązano z oddziaływaniem tekstu (czy też przedstawienia) na odbiorcę. Jedność, zdaniem ówczesnych estetyków, stanowiła zarówno - w wariancie nastawionym bardziej na odbiór in-

\footnotetext{
${ }^{59}$ Tamże, s. 155.

${ }^{60}$ E. Słowacki, O poezji, s. 76.

${ }^{61} \mathrm{~K}$. Brodziński, Literatura polska..., s. 287.
} 
telektualny - warunek pojęcia, a więc zrozumienia, utworu, jak i - u podkreślających bardziej uczuciowy charakter kontaktu ze sztuką - warunek emocjonalnego zaangażowania odbiorcy. Stąd też, choć obowiązywała dla wszystkich gatunków literackich, zasady jej realizowania określane były różnie, zależnie od typu tekstu. Nie wynikało to z rzekomego fetyszyzowania podziałów genologicznych i obowiązujących w poszczególnych gatunkach reguł, lecz ze świadomości różnego funkcjonowania poszczególnych typów tekstów, różnych modeli ich odbioru i różnych oczekiwań odbiorcy wobec nich: innych na przykład w wypadku oglądania przedstawienia teatralnego niż lektury eposu. Dzieło etyczne i estetyczne, nauczające i sprawiające przyjemność nie mogło być pozbawione jedności, która zgodnie z ówczesnymi przekonaniami dotyczącymi naszej percepcji stanowiła warunek zarówno jednego, jak i drugiego. 


\title{
SŁOWA KLUCZOWE:
}

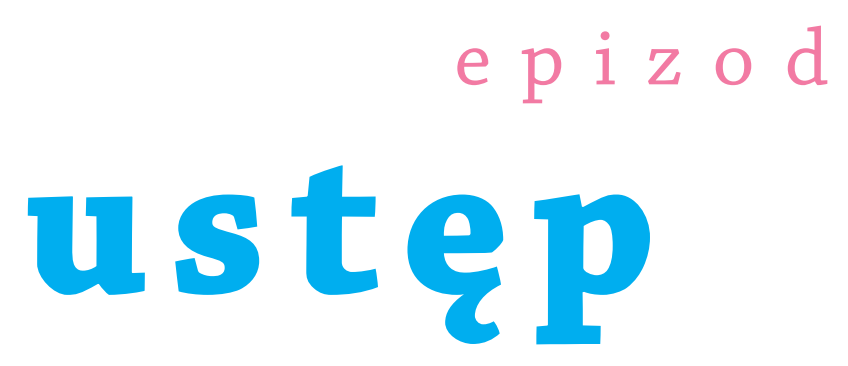

trzy jedności

\begin{abstract}
AbSTRAKT:
Artykuł poświęcono teorii „epizodów” w poetyce polskiej dwóch pierwszych dziesięcioleci XIX wieku. Przeanalizowano w nim teksty związane z nurtem klasycyzmu postanisławowskiego, zawierające wskazania dotyczące wprowadzania do utworu literackiego fragmentów niezwiązanych z jego głównym wątkiem, zwanych ustępami. W celu odtworzenia teorii warunkującej funkcjonowanie tych swoistych „dodatków” konieczna okazała się analiza jednej z podstawowych kategorii estetycznych epoki - kategorii jedności. Zostaje ona powiązana z ówczesną teorią percepcji dzieła sztuki mającą swoje korzenie w filozofii kartezjańskiej. W ten sposób rozważania o epizodach i jedności stają się punktem wyjścia do weryfikacji obiegowych przekonań o arbitralności klasycystycznych „reguł”.
\end{abstract}




\section{klasycyzm postanisławowski}

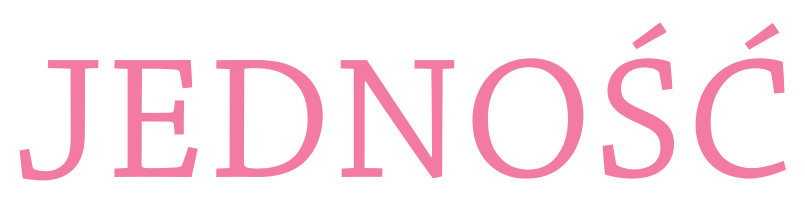

\section{NOTA O AUTORZE:}

Helena Markowska - doktorantka w Zakładzie Poetyki, Teorii Literatury i Metodologii Badań Literackich w Instytucie Literatury Polskiej Wydziału Polonistyki Uniwersytetu Warszawskiego, absolwentka polonistyki i kulturoznawstwa - cywilizacji śródziemnomorskiej w ramach studiów w Kolegium MISHiS UW. Interesuje się literaturą romantyzmu i późnego oświecenia. Obecnie bada naukę o literaturze czasów przełomu oświeceniowo-romantycznego oraz początki polskiego literaturoznawstwa akademickiego na Uniwersytecie Warszawskim i Uniwersytecie Wileńskim. Szczególne miejsce w kręgu jej zainteresowań zajmują także Juliusz Słowacki (artykuł Bezsilne przekleństwa Juliusza Słowackiego. O bezbożności dramatu Mindowe, opublikowany w „Przeglądzie Humanistycznym" 2012, nr 4) oraz Litwa. Pracę magisterską poświęciła postaci Mendoga w literaturze polskiej. 